\title{
HER2 testing: The patent "genee" is out of the bottle
}

\section{Brian Goldman}

$\mathrm{S}$ ince the first rough draft of the human genome was completed in 2000, the public has waited patiently for the benefits that were promised breathlessly by researchers. Increasingly, these benefits come at a steep price.

According to Jensen and Murray, ${ }^{1}$ more than 4000 of the nearly 24000 known human genes have been patented in the United States. Of these patents, $63 \%$ have been assigned to private corporations and $28 \%$ have been assigned to institutions such as hospitals and universities or to foundations set up by these institutions to own and exploit their patents. ${ }^{1}$ Genes are being patented almost as quickly as they are discovered; it is estimated that private corporations have filed more than 20000 preliminary patent applications for human genes. ${ }^{2}$

Gene patents cover much more than genetic testing and potential treatments. Many patents cover the genes themselves. The gene may occur naturally in humans, but the person who discovers the gene usually holds the patent. As the list of patented genes increases, there are growing fears about the impact on everything from research to the practice of medicine itself.

The example of human epidermal growth factor receptor2 (HER2) and trastuzumab (Herceptin) illustrates both the promise and the perils of gene patenting. Trastuzumab is an antibody against the product of a known breast cancer oncogene; it acts on HER 2 either to inhibit cancer cell proliferation or to signal the immune system to destroy the cancer cell. Trastuzumab therapy has been shown to increase survival among women with metastatic as well as localized breast cancer.

All innovative drugs are patented, so why shouldn't drugs such as trastuzumab be patented as well? The difference in this case is that the trastuzumab patent holder (Genentech Inc.) also holds multiple patents related to the HER 2 gene and HER 2 ligands. ${ }^{3-5}$ The implications of this are enormous: any researcher or pharmaceutical company who wants to develop a breast cancer treatment based on the HER2 gene must obtain permission from Genentech or risk being sued for patent infringement.

Given the above, it is not surprising that the drug is as expensive as it is. The annual cost of trastuzumab therapy in Canada is as high as $\$ 50000 .{ }^{6}$ The cost of tamoxifen is much lower. Currently, the cost of trastuzumab is covered according to eligibility criteria set by provincial cancer care agencies $\sim$ or by individual hospitals that provide cancer care.

One can argue that the study by Dendukuri and colleagues ${ }^{7}$ in this issue of CMAJ (page I429) is necessary only because patenting issues have made the drug so expensive. For the drug to be effective against breast cancer, the cancer must be HER 2 positive (overexpress the HER2 gene). About $25 \%$ of all breast cancers are HER 2 positive. ${ }^{8}$ Given how expensive trastuzumab is and how many women with breast cancer could benefit from this drug, it is critical that the provinces find the most cost-effective way of determining HER 2 status.

There are other cost implications of gene patenting. Myriad Genetics Inc., a US biopharmaceutical company, has obtained patents in the United States and Canada on the breast cancer genes $B R C A I$ and $B R C A 2$ (breast cancer I and 2, early onset). BRCAI and BRCA2 mutations have been found in about 10\% of breast cancer cases. In 200I, when the provinces started testing for $B R C A I$ and $B R C A 2$ mutations at publicly funded Canadian laboratories, Myriad Genetics alleged patent infringement and demanded that all testing be performed at its laboratories in the United States. Testing at Myriad Genetics costs 2-3 times more than in Canada. In July 200I Myriad issued a cease and desist notice in Canada. British Columbia stopped all testing at that time but offered to facilitate testing by Myriad Genetics for patients willing to pay. The province later sidestepped this claim by sending samples to Ontario for testing. ${ }^{9}$ In Quebec, $B R C A I$ and $B R C A 2$ testing was performed at Myriad Genetics. Other provinces such as Alberta, Ontario and Manitoba continued to offer the testing in Canada.

Critics of gene patenting also say that the practice slows and even halts scientific progress by discouraging scientists from doing research on patented genes. Hereditary hemochromatosis is an autosomal recessive disease affecting mainly people of European descent. Up to $85 \%$ of cases of hemochromatosis are caused by 2 mutations in the hemochromatosis gene (HFE; $\mathrm{H}_{3} \mathrm{D}$ and $\mathrm{C}_{2} 82 \mathrm{Y}$ ). Before patents on the HFE mutations were awarded, many US laboratories performed testing for the mutations. According to a survey published in 2002, ${ }^{10} 30 \%$ of respondents reported that they stopped developing a genetic test or stopped testing for HFE mutations altogether after the gene was patented. According to the authors of the survey, ${ }^{10}$ the result has been that validation of genetic testing for hemochromatosis has not proceeded as quickly as it would have had the mutations not been patented.

Currently under Canadian law, a gene can be patented if it meets 3 criteria: it is regarded as a new invention; this "invention" works and is of interest to industry; and the discovery is not so obvious that anyone working in the field could have made it. Patents are not awarded for medical and surgical procedures. These procedures are in the public domain so that all of society can benefit from them. Why should genes be treated differently?

Proponents of gene patenting say that patents are necessary to provide incentives for innovation, to recover the costs of research and development and to attract investment capital. Given that, this practice is not likely to end soon. The 
key, therefore, is to offer patent protection while protecting society's right to benefit from new discoveries. Some have called for the creation of an independent, nonprofit patent clearing house whose aim would be to ensure a fair financial return for patent holders and fair access to genetic discoveries for researchers. ${ }^{11}$

The danger is that patent holders will fail to cooperate in the formation of such an agency. As genetic testing and treatment with gene-based therapies become routine, the prohibitive expense of gene patenting will become clearer. At that point, governments will probably have to take action to make certain that gene discoveries will be available to all and not just to those who can afford them. The stakes are too high to leave this issue to the vagaries of the "market." Already, this government action has begun: in 2004 the European Patent Office revoked the patent it granted to Myriad Genetics for the BRCAI breast cancer gene. In Canada, Alberta, Manitoba and Ontario have defied Myriad Genetics and offer BRCAI and $B R C A 2$ testing.

Brian Goldman is "House Doctor" on CBC Radio One stations across Canada and is an Assistant Professor in the Department of Family and Community Medicine, University of Toronto.

Competing interests: None declared.

\section{REFERENCES}

I. Jensen K, Murray F. Intellectual property. Enhanced: intellectual property landscape of the human genome. Science 2005;310:239-40.

2. Widge A; American Medical Student Association. Patent pending: a primer on gene patents. Virginia: The Association; 200I. Available: www.amsa.org/pdf Igenepatents.pdf (accessed 2007 Apr 3).

3. Hudziak RM, Shepard HM, Ullrich A, inventors. Genentech, Inc., assignee. HER2 extracellular domain. US patent 6015567. 2000 Jan I8.

4. Vandlen RL, Holmes WE, inventors. Genentech, Inc., assignee. Method for purifying heregulin. US patent 5641869. I997 June 24.

5. Vandlen RL, Holmes WE, inventors. Genentech, Inc., assignee. Structure, production and use of heregulin. US patent 5367060. I994 Nov 22.

6. Norum J, Risberg T, Olsen JA. A monoclonal antibody against HER-2 (trastuzumab) for metastatic breast cancer: a model-based cost-effectiveness analysis. Ann Oncol 2005;6:909-I4.

7. Dendukuri N, Khetani K, McIsaac M, et al. Testing for HER2-positive breast cancer: a systematic review and cost-effectiveness analysis. $C M A J$ 2007;176:1429-34.

8. Slamon DJ, Godolphin W, Jones LA, et al. Studies of the HER-2/neu proto-oncogene in human breast and ovarian cancer. Science 1989;244:707-I2.

9. Kent H. British Columbia sidesteps patent claim, transfers BRCA gene testing to Ontario. CMAJ 2003;168:21I.

Io. Merz JF, Kriss AG, Leonard DGB, et al. Diagnostic testing fails the test. Nature 2002; 4I5:577-9.

II. Sheremeta L, Gold ER. Creating a patent clearinghouse in Canada: a solution to problems of equity and access. Genome Canada $\mathrm{GE}^{3}$ LS Winter Symposium; 2003 Feb 6-8; Montreal.

Correspondence to: Dr. Brian Goldman, Assistant Professor, Department of Family and Community Medicine, University of Toronto, Rm. 206, Mount Sinai Hospital, 600 University Ave., Toronto, ON M5G IX5; fax 4I6 586-47I9; drhbg@rogers.com 